\title{
Surgical Management of Fistulating Perianal Crohn's Disease - A UK Survey
}

Article in Colorectal Disease · July 2016

DOI: $10.1111 /$ codi.13462

CITATIONS

6

33 authors, including:
READS

121

\section{Matthew James Lee}

Sheffield Teaching Hospitals NHS Foundatio... 60 PUBLICATIONS 41 CITATIONS

SEE PROFILE

\section{Steven R Brown}

Sheffield Teaching Hospitals NHS Foundatio..

193 PUBLICATIONS 3,755 CITATIONS

SEE PROFILE

\section{Nick A Heywood}

University Hospital Of South Manchester NH... 22 PUBLICATIONS 42 CITATIONS

SEE PROFILE

\section{Nicola Fearnhead}

Cambridge University Hospitals NHS Founda... 63 PUBLICATIONS 1,376 CITATIONS

SEE PROFILE

Some of the authors of this publication are also working on these related projects: 
Received Date : 27-Apr-2016

Revised Date : 03-Jun-2016

Accepted Date : 08-Jun-2016

Article type : Original Article

\section{Surgical Management of Fistulating Perianal Crohn's Disease - A UK Survey}

MJ Lee ${ }^{1,2,3}$, N Heywood $^{4,5}$, PM Sagar ${ }^{6}$, SR Brown $^{1}$, NS Fearnhead ${ }^{7}$ and pCD Collaborators*

1. Department of General Surgery, Sheffield Teaching Hospitals, Sheffield, UK

2. Department of Oncology and Metabolism, Medical School, University of Sheffield, UK

3. South Yorkshire Surgical Research Group

4. University Hospital South Manchester, Manchester, UK

5. North-West Research Collaborative

6. St James University Hospital, Leeds, UK

7. Addenbrooke's Hospital, Cambridge, UK

*Collaborative authors listed in appendix.

Corresponding author

Matthew Lee

Department of General Surgery, Sheffield Teaching Hospitals, Sheffield, UK

Tel: +44 (0) 1142434343

Fax: +44 (0) 1142560472

Email: m.j.lee@sheffield.ac.uk

Twitter: @wannabehawkeye

Funding:

Meeting costs of the steering group were funded by the Bowel Disease Research Fund and the Royal College of Surgeons of England, as part of the BDRF Delphi Exercise.

Ethics:

This is a service evaluation, so ethical application is not required.

Conflicts of interest:

The authors report no conflicts of interest.

Keywords: Crohn's disease, Anal Fistula, Survey

This article has been accepted for publication and undergone full peer review but has not been through the copyediting, typesetting, pagination and proofreading process, which may lead to differences between this version and the Version of Record. Please cite this article as doi: 10.1111/codi.13462

This article is protected by copyright. All rights reserved. 


\begin{abstract}
Aim: Around one-third of patients with Crohn's disease are affected by Crohn's fistula-inano $(p C D)$. It typically follows a chronic course and patients undergo long-term medical and surgical therapy. We set out to describe current surgical practice in the management of pCD in the UK.
\end{abstract}

Methods: A survey of surgical management of $\mathrm{PCD}$ was designed by an expert group of colorectal surgeons and gastroenterologists. This assessed acute, elective, multidisciplinary and definitive surgical management. A pilot of the questionnaire was undertaken at the Digestive Disease Federation 2015 meeting. The survey was refined and distributed nationally through the trainee collaborative networks.

Results: National rollout obtained responses from 133 surgeons of 179 approached (response rate $74.3 \%$ ). At first operation, $32 \%$ surgeons would always consider drainage of sepsis and $31.1 \%$ would place a draining seton. At first elective operation, $66.6 \%$ would routinely insert of draining seton, and $84.4 \%$ would avoid cutting seton. The IBD multidisciplinary team was available to $87.6 \%$ respondents, although only $25.1 \%$ routinely discussed pCD patients. Anti-TNF- $\alpha$ therapy was routinely considered by $64.2 \%$, although $44.2 \%$ left medical management to gastroenterology. Common definitive procedures were removal of seton only (70.7\%), fistulotomy (57.1\%), advancement flap (38.9\%), fistula plug (36.4\%) and ligation of intersphincteric track (LIFT) procedure (31.8\%). Indications for diverting stoma or proctectomy were intractable sepsis, incontinence, and poor quality of life.

Discussion: This survey has demonstrated areas of common practice, but has also highlighted divergent practice including choices of definitive surgery and multimodal management. Practical guidelines are required to support colorectal surgeons in the UK.

\title{
What does this paper add to the literature?
}

This study describes variation in surgical management of fistulating perianal Crohn's disease across the UK, and is a first step towards establishing UK practice guidelines.

This article is protected by copyright. All rights reserved. 


\section{Introduction}

Perianal disease affects an estimated 34\% of patients with Crohn's disease, with a Crohn's fistula-in-ano occurring in around $60 \%$ of patients. $[1,2]$. Perianal fistulating disease (pCD) represents a significant challenge for patients, physicians and surgeons. Despite advances in treatment, long-term remission will only be achieved for two thirds of patients with simple fistulae and just a third of patients with complex fistulae [3].

Due to the paucity of large scale, well-designed, controlled trials, the majority of guidelines for managing perianal fistulating disease are based on consensus of expert opinion. Much of the published literature focuses on medical management, leaving gaps in guidance for surgeons $[4,5]$.

A multidisciplinary approach appears to improve quality of care for patients with $C D[9]$, however, the medical and surgical approach to its management may differ. The recent Delphi exercise by the Bowel Disease Research Foundation and the Association of Coloproctology of Great Britain and Ireland (ACPGBI) has identified the management of fistulating $\mathrm{PCD}$ as an area requiring further research[10]. Using the established surgical research collaboratives[11] we sought to identify variations in current surgical management of this debilitating condition.

The aim of this study was to report current colorectal practice in the surgical management of fistulating perianal Crohn's disease in the United Kingdom (UK).

This article is protected by copyright. All rights reserved. 


\section{Method}

The survey was devised by a group of surgeons and gastroenterologists with an interest in inflammatory bowel disease (IBD), and further assessed and altered by patient consultation. The questionnaire was designed to audit practice in four areas: assessment and management of acute presentation, assessment and management of elective presentation, multidisciplinary management and definitive surgical management. Questionnaires were anonymous at respondent level.

The questions asked are included in the data tables 1-5 included in the results section. Responses were designed to be either binary (Yes/No), describe frequency using a four point scale (always, sometimes, occasionally, never), or selection of options from a menu. Where options were provided, instructions of 'select one' or 'select as many as apply' were clear, with an 'other' option provided.

A pilot of the survey was undertaken at the Digestive Disorders Federation (London July 2015), with instructions to complete the survey and to offer critique of questions where appropriate. Following critique of the questionnaire, minor clarifications were made to wording of two questions, the option set was changed for two questions to widen range of timing options, and one additional option was included in a question on treatment.

The full questionnaire was run through the UK surgical trainee research collaboratives, led jointly by the South Yorkshire Surgical Research Group (SYSuRG) and the North-West Research Collaborative (NWRC). Collaborators were asked to deliver the questionnaire to consultant colorectal surgeons in their units. Initial contact was made via the National Research Collaborative email lists and electronic contact made to local collaborative leads and cascaded locally. Collaborators were asked to support delivery of hard-copy questionnaires locally to Consultants and return at least three completed questionnaires to the Research Electronic Data Capture ${ }^{\mathrm{TM}}$ (REDCap) system, hosted by the University of Sheffield [12]. Although questionnaires were anonymous at respondent level, the number of centres and participants included was recorded by collaborators.

This article is protected by copyright. All rights reserved. 
Numerical data from the questionnaire was collated and presented in a descriptive manner only. Where binary answers were changed to four point answers for the final study, yes and no options were analysed as 'always' and 'never' responses respectively. Free text data on indications for stoma and proctectomy were collated and representative statements reported.

Ethical approval was not required for service evaluation of current practice.

\section{Results}

In the pilot phase, 35 questionnaires were distributed and 21 were returned (response rate $60 \%)$. In the full review phase, 133 responses were received from a potential population of 179 Consultant colorectal surgeons in participating centres ( $74.3 \%$ response rate). Of these, 70 practised in district general hospitals and 63 in teaching hospitals, accounting for 32 different centres across the UK, including centres in Wales and Scotland. For final analysis, both phases were pooled, giving a total of 154 responses of 214 (71.9\% of all distributed questionnaires).

\section{Acute management of perianal sepsis}

This section addressed patients admitted acutely with perianal symptoms. There was variation in the use of perioperative antibiotics in the acute setting, with $39.6 \%$ of respondents always using them and 5.8\% never using them. Most respondents (42.2\%) would start antibiotic therapy pre-operatively on the ward or in clinic, with $40.9 \%$ starting therapy at induction of anaesthesia. The antibiotic of choice was metronidazole (77.9\%), followed by co-amoxiclav (35.1\%) and ciprofloxacin (20.1\%). Few respondents would always ask for pre-operative imaging in the acute setting (7.1\%), but the majority would seek imaging frequently (37.0\%) or occasionally (51.9\%). Where imaging was used, magnetic resonance imaging (MRI) of the pelvis was the preferred modality (96.1\%), with a small minority using endo-anal ultrasound (2.5\%) or CT (1.9\%).

Where the diagnosis of Crohn's disease was suspected but not yet established, respondents were asked to report which investigations they would use to confirm or refute this. Faecal calprotectin was routinely used by $22.9 \%$, colonoscopy always used by $57.1 \%$, flexible

This article is protected by copyright. All rights reserved. 
sigmoidoscopy always used by $16.8 \%$ and MR small bowel by $9.7 \%$. Conversely, $25 \%$ of respondents would never use faecal calprotectin to aid diagnosis, 3.2\% would not use colonoscopy, $18 \%$ would not use flexible sigmoidoscopy, and $13.6 \%$ would not use MR of small bowel. No respondents routinely used video capsule endoscopy (VCE) to confirm diagnosis of Crohn's disease, and $40.2 \%$ would never use VCE in this setting (Table 1 ).

\section{Crohn's fistula in acute setting.}

We asked respondents to identify which procedures they would routinely consider in an operation for an acutely symptomatic/emergency presentation of $\mathrm{pCD} ; 32 \%$ would drain sepsis, $31.1 \%$ would consider placement of a draining seton if appropriate, and $0.6 \%$ would consider excision of fistula track. The majority of respondents (89.6\%) indicated that they would never consider a cutting seton in this setting (Table 2).

Respondents reported on what advice they would give to a less experienced surgeon (a general surgical colleague or registrar) undertaking surgery in this setting. Responses tended to recommend a more conservative approach with $43.5 \%$ advocating drainage of sepsis $19.5 \%$ advocating placement of a draining seton, and $94.8 \%$ advising against a cutting seton. Free text comments from two respondents indicated a feeling that only an experienced colorectal surgeon should be undertaking these procedures.

\section{Subsequent elective surgery}

The survey elicited procedure preferences for the first subsequent elective examination under anaesthetic (EUA). As in the acute setting, draining seton was routinely considered (66.6\%) and cutting seton was avoided (84.4\%). Where preferences were indicated, Ethibond $®$ (Ethicon) was the preferred seton material for $41.5 \%$, silastic slings for $24.6 \%$ and comfort drains ${ }^{\circledR}$ (Agency for Medical Innovation) in 3.2\%. Other procedures such as excision of track, fistulotomy and faecal diversion were not considered options in this context by $62.9 \%, 35.7 \%$ and $33.1 \%$ of surgeons respectively.

This article is protected by copyright. All rights reserved. 
If a fistula was found at EUA, $30.6 \%$ would routinely undertake post-operative MRI. If a fistula was not identified, but suspected, $63.9 \%$ would routinely undertake post-operative MRI. Routine repeat EUA would be performed by $16.5 \%$ of respondents, although $75.9 \%$ of respondents indicated that they would frequently or occasionally undertake repeated EUA, suggesting a 'selected case' approach. Post-operative antibiotics were routinely used by $11.2 \%$ of respondents, and in selected cases (frequently/occasionally) by $75.0 \%$ (Table 3 ).

\section{Medical and multi-modal management of $p C D$}

An inflammatory bowel disease MDT was available to $87.6 \%$ of respondents. Of these, $25.1 \%$ routinely discussed all cases of pCD in this setting and only $0.7 \%$ of respondents never discussed patients. A multi-modal approach utilising joint medical and surgical therapy was routinely used by $28.6 \%$ of respondents, with just $1.9 \%$ not using a combined approach (Table 4).

Gastroenterology follow-up was arranged for all patients by $71.4 \%$ of respondents. Immunosuppressant therapy was routinely used in treatment of this condition by $32.8 \%$ of respondents, with $58.8 \%$ indicating a selected-case approach. Eight responses were excluded from this analysis as their response from the pilot survey could not be mapped to the final questionnaire.

Surgeons were asked to identify which drug(s) they would prefer a patient to receive as part of multi-modal care. Anti-TNF- $\alpha$ therapy was most frequently preferred (64.2\%), followed by azathioprine (33.7\%). Despite expressing preferences, the final decision on medical management was left with a gastroenterologist by $42.2 \%$ of surgeons. Summary of results is presented in Table 4.

The decision on seton removal was made by surgeons in $64.2 \%$ of cases, the multidisciplinary team in $33.7 \%$ of cases and by gastroenterologists in $5.8 \%$ of cases. The patient made the decision for seton removal in $4.5 \%$ of responses. A free-text option was available to report timing of seton removal. Responses indicated that this was highly variable and tailored to the patient. In some cases, timings were related to surgery e.g. 3 
months post-op, and in others related to biologic therapy e.g. after third dose. Respondents also indicated that it might be left in-situ indefinitely.

\section{Definitive Surgical Management of $p C D$}

Eleven surgical procedures were considered as options by respondents as options to facilitate definitive closure of a fistula. The most frequently considered options were removal of seton only (70.7\%), fistulotomy (57.1\%), advancement flap (38.9\%), fistula plug (36.4\%) and ligation of intersphincteric track (LIFT) procedure (31.8\%). Fistulectomy (27.9\%), fibrin glue (12.9\%) and local perineal flaps (7.8\%) were used by fewer respondents. Early adopters of technology indicated use of over the scope clip (OTSC) (1.2\%), video assisted fistula closure (VAAFT) (1.9\%) and fistula-assisted laser closure (FiLaC'M) (0.6\%).

Most respondents used diverting stoma and proctectomy on a selected case basis, with only $12.3 \%$ of respondents never using a stoma and $12.9 \%$ never considering proctectomy. Freetext responses defining indications for these were similar with the phrase 'failed bottom' used by many respondents. This was defined as recurrent or chronic perianal sepsis, incontinence, and symptoms or proctitis refractory to medical therapy. Dysplasia and malignancy were reported as specific indications for proctectomy. Patient choice was identified by several respondents as a factor in their decision to undertake these procedures. Where proctectomy was performed, a small perineal defect would be primarily closed, but respondents preferred flap-based perineal reconstruction if a large defect remained.

A significant minority $(41.5 \%)$ of respondents indicated that they would treat rectovaginal fistula. This group of respondents would use definitive procedures including advancement flap (21.5\%), fistula plug (10.9\%), Martius flap (9.3\%), omental interposition (6.2\%) and LIFT procedure (4.6\%) to treat recto-vaginal fistula. A diverting stoma would be used by $6.2 \%$ of respondents. A summary of definitive options used in perianal and rectovaginal fistulae are presented in Table 5.

This article is protected by copyright. All rights reserved. 


\section{Discussion}

This study has used a collaborative approach to assess current UK surgical practice in fistulating perianal Crohn's disease. It has identified areas of common practice, including choice of imaging modality, antibiotics and avoidance of sphincter-disrupting treatments such as a cutting seton. The survey has clearly exposed variation in practice in the management of fistulating perianal Crohn's disease.

There are limitations associated with survey-based research including responder bias. We attempted to address these in the study design by using personal contacts and traineeconsultant relationships with the opportunity for case-based discussions over impersonal electronic surveys with attendant poor response rates. Mitigation against survey fatigue due to length of questionnaire was also evident in engagement of local collaborators to deliver and complete the questionnaire. Anonymous participation in the survey may also have helped improve response rates, as there was no concern about identification or challenge related to practice. The high response rate was achieved with the support of the trainee collaborative networks.

Management of a condition with variable presentations and degrees of severity such as fistulating perianal Crohn's disease, will inevitably lead to some difficulties in achieving clear agreement around routine practice as management is rightly tailored to each case. This is reflected by the high proportion of respondents who selected 'frequently' or 'occasionally' as options.

There is little evidence on the use of antibiotics alone in the treatment of perianal Crohn's disease, with meta-analyses on the use of ciprofloxacin suggesting a marginal effect in remission of Crohn's fistula $[13,14]$. In combination with Adalimumab, it may offer additional benefit in healing [15]. Recent American guidelines suggest that antibiotics in perianal sepsis might be of benefit only in the immunosuppressed, or where there is systemic upset or cellulitis [16].

This article is protected by copyright. All rights reserved. 
Magnetic resonance imaging is well established as the imaging modality of choice in perianal Crohn's disease, and has been used to guide therapy in one study [17]. Endo-anal ultrasound is not yet a widely used technology. It has a niche role here as a diagnostic adjunct in specialist hands [18],but has limitations depending on the type of fistula present [19].

Surgeons used a variety of investigations for establishing the diagnosis of Crohn's disease. Faecal calprotectin is a sensitive marker of mucosal inflammation, so may be raised in a number of non-Crohn's related scenarios [20,21]. Endoscopic assessment allows visual and histologic assessment of the colon. The split between colonoscopy and flexible sigmoidoscopy may be associated with surgeons ruling out proctitis only rather than assessing the whole colon, as proctitis is a prognostic factor in mucosal healing [4] and also in persistence of fistula.

The roles of anti-TNF- $\alpha$ therapy and azathioprine are well established in this setting, so their positions as drugs of choice are merited $[17,22,15]$. Previous work has demonstrated that steroids should not be used for $\mathrm{PCD}$ alone, and their use in this setting runs counter to current guidelines $[23,4]$. The use of steroids to treat associated luminal disease may be appropriate, and it is possible that this factor was considered when responding to questions about best medical therapy [23].

In both acute and initial elective settings, the survey shows a tendency towards conservative and sphincter-preserving procedures, in the form of drainage of sepsis and use of draining seton. Respondents widely rejected the use of cutting setons in this group of patients. Patients with $\mathrm{PCD}$ tend to a chronic and recurrent disease course necessitating multiple interventions, and therefore efforts should be made to preserve continence where possible [24]. The conservative advice given to less experienced surgeons suggests UK practice is aimed at avoiding iatrogenic exacerbation of fistulating disease and tends to favour management by experienced colorectal surgeons.

This article is protected by copyright. All rights reserved. 
The removal of seton timing varied with treatment intent, although in free text comments, respondents indicated that they tended to follow one of two published UK practices $[17,25]$. The perceived advantage of early removal of a seton is the removal of a 'splint' maintaining patency of a fistula and allowing it to heal. The trade off is that removal too early in the treatment process might promote recurrent perianal sepsis.

There is a wide range of procedures offered as definitive surgical options for patients with pCD. Draining seton alone, fistulotomy, fistula plug and LIFT have been described in the literature, with varying outcomes, although this is mostly observational and not trial based data[26,27,24]. The variety of choice in definitive surgery may reflect in part a lack of consensus and limited evidence for the surgical management of $p C D$, but may also be influenced by individual surgeon expertise.

Much of the recent literature has focussed on a multimodal approach to $p C D$, with emphasis on sepsis control and institution of medical therapy (e.g. biologics) to aid fistula closure showing benefit over surgery alone $[28,29]$. Current trials are investigating various permutations of this approach [30]. It is encouraging that most respondents have access to an IBD MDT and utilise immunosuppressant drugs as part of their therapy, although only $28 \%$ routinely employ this approach. This study did not explore make-up of the IBD MDT or whether it was supported at a local or regional level.

This study reported that some surgeons do not undertake proctectomy or stoma formation, or manage Crohn's rectovaginal fistula. In light of the varied definitive options described, it is possible that a number of surgeons will simply place a seton and not offer any surgical options beyond that, perhaps preferring to refer on to specialist colleagues. Single centre experience with rectovaginal fistula, even in tertiary or quaternary centres comes from small cohorts [31,32]. As volume is associated with outcome in some aspects of colorectal surgery [33], perhaps centralisation of definitive surgery for $\mathrm{PCD}$ should be considered. This might offer better outcomes, but risks losing local expertise in peripheral hospitals [34]. Those who do undertake proctectomy or stoma formation broadly agreed on indications for these procedures. It is of note that patient preference or request was a recognised

This article is protected by copyright. All rights reserved. 
indication, as quality of life in patients with $\mathrm{PCD}$ has been found to be improved in patients who have a stoma [35].

\section{Conclusion}

This study reports on individual surgical approaches to PCD in the context of trends in national practice. Variation in practice will have implications for design of and implementation of future research interventions in $\mathrm{PCD}$. Further work is required to reach consensus on standardisation of the PCD management pathway. In the interim, early and efficient control of sepsis, multimodal pCD management, and an emphasis on sphincterpreserving surgical techniques are the current foundations of managing $p C D$ in the UK.

\section{References}

1. Singh B, Mortensen NJ, Jewell DP, George B (2004) Perianal Crohn's disease. Br J Surg 91 (7):801-814. doi:10.1002/bjs.4613

2. Safar B, Sands D (2007) Perianal Crohn's disease. Clin Colon Rectal Surg 20 (4):282-293. doi:10.1055/s-2007-991027

3. Molendijk I, Nuij VJ, van der Meulen-de Jong AE, van der Woude CJ (2014) Disappointing durable remission rates in complex Crohn's disease fistula. Inflamm Bowel Dis 20 (11):20222028. doi:10.1097/MIB.0000000000000148

4. Gecse K, Bemelman W, Kamm M, Stoker J, Khanna R, Ng S, Panes J, van Assche G, Liu Z, Hart A, Levesque B, D'Haens G (2014) A global consensus on the classification, diagnosis and multidisciplinary treatment of perianal fistulising Crohn's disease. Gut 63 (9):1381-1392. doi:10.1136/gutjnl-2013-306709

5. Van Assche G, Dignass A, Reinisch W, van der Woude C, Sturm A, De Vos M, Guslandi M, Oldenburg B, Dotan I, Marteau P, Ardizzone A, Baumgart D, D'Haens G, Gionchetti P, Portela F, Vucelic B, Soderholm J, Escher J, Koletzko S, Kolho K, Lukas M, Mottet C, Tilg H, Vermeire $S$, Carbonnel F, Cole A, Novacek G, Reinshagen M, Tsianos E, Herrlinger K, Oldenburg B, Bouhnik Y, Kiesslich R, Stange E, Travis S, Lindsay J (2010) The second European evidencebased Consensus on the diagnosis and management of Crohn's disease: Special situations. J Crohns Colitis 4 (1):63-101. doi:10.1016/j.crohns.2009.09.009

6. Pozo-Rodriguez F, Lopez-Campos JL, Alvarez-Martinez CJ, Castro-Acosta A, Aguero R, Hueto J, Hernandez-Hernandez J, Barron M, Abraira V, Forte A, Nieto JMS, Lopez-Gabaldon E, Cosio BG, Agusti A, Grp AS (2012) Clinical Audit of COPD Patients Requiring Hospital Admissions in Spain: AUDIPOC Study. PloS one 7 (7). doi:ARTN e42156 10.1371/journal.pone.0042156

7. Price LC, Lowe D, Hosker HSR, Anstey K, Pearson MG, Roberts CM, Ph BTSRC (2006) UK National COPD Audit 2003: impact of hospital resources and organisation of care on patient outcome following admission for acute COPD exacerbation. Thorax 61 (10):837-842. doi:10.1136/thx.2005.049940

8. Chung SC, Sundstrom J, Gale CP, James S, Deanfield J, Wallentin L, Timmis A, Jernberg T, Hemingway $\mathrm{H}$ (2015) Comparison of hospital variation in acute myocardial infarction care

This article is protected by copyright. All rights reserved. 
and outcome between Sweden and United Kingdom: population based cohort study using nationwide clinical registries. Bmj-Brit Med J 351. doi:Artn H3913

10.1136/Bmj.H3913

9. Ricci C, Lanzarotto F, Lanzini A (2008) The multidisciplinary team for management of inflammatory bowel diseases. Digestive and liver disease : official journal of the Italian Society of Gastroenterology and the Italian Association for the Study of the Liver 40 Suppl 2:S285-288. doi:10.1016/S1590-8658(08)60539-3

10. Tiernan J, Cook A, Geh I, George B, Magill L, Northover J, Verjee A, Wheeler J, Fearnhead $\mathrm{N}$ (2014) Use of a modified Delphi approach to develop research priorities for the association of coloproctology of Great Britain and Ireland. Colorectal Dis 16 (12):965-970. doi:10.1111/codi.12790

11. Bhangu A, Kolias AG, Pinkney T, Hall NJ, Fitzgerald JE (2013) Surgical research collaboratives in the UK. Lancet 382 (9898):1091-1092

12. Harris PA, Taylor R, Thielke R, Payne J, Gonzalez N, Conde JG (2009) Research electronic data capture (REDCap) - A metadata-driven methodology and workflow process for providing translational research informatics support. J Biomed Inform 42 (2):377-381 13. Wu XW, Ji HZ, Wang FY (2015) Meta-analysis of ciprofloxacin in treatment of Crohn's disease. Biomed Rep 3 (1):70-74. doi:10.3892/br.2014.368

14. Su JW, Ma JJ, Zhang HJ (2015) Use of antibiotics in patients with Crohn's disease: a systematic review and meta-analysis. J Dig Dis 16 (2):58-66. doi:10.1111/1751-2980.12216 15. Dewint $P$, Hansen $B E$, Verhey $E$, Oldenburg $B$, Hommes $D$, Pierik $M$, Ponsioen $C l$, van Dullemen HM, Russel M, van Bodegraven AA, van der Woude CJ (2014) Adalimumab combined with ciprofloxacin is superior to adalimumab monotherapy in perianal fistula closure in Crohn's disease: a randomised double-blind, placebo controlled trial (ADAFI). Gut 63:292-299

16. Steele SR, Kumar R, Feingold DL, Rafferty JL, Buie WD, Standards Practice Task Force of the American Society of C, Rectal S (2011) Practice parameters for the management of perianal abscess and fistula-in-ano. Dis Colon Rectum 54 (12):1465-1474.

doi:10.1097/DCR.0b013e31823122b3

17. Tozer P, Ng SC, Siddiqui MR, Plamondon S, Burling D, Gupta A, Swatton A, Tripoli S, Vaizey CJ, Kamm MA, Phillips R, Hart A (2012) Long-term MRI-guided combined anti-TNFalpha and thiopurine therapy for Crohn's perianal fistulas. Inflamm Bowel Dis 18 (10):18251834. doi:10.1002/ibd.21940

18. Siddiqui MR, Asrafian H, Tozer P, Daulatzai N, Burling D, Hart A, Athanasiou T, Phillips R (2012) A diagnostic accuracy meta-analysis of endoanal ultrasound and MRI for perianal fistula assessment. Dis Colon Rectum 55 (5):576-585

19. Alabiso ME, lasiello F, Pellino G, lacomino A, Roberto L, Pinto A, Riegler G, Selvaggi F, Reginelli A (2016) 3D-EAUS and MRI in the Activity of Anal Fistulas in Crohn's Disease. Gastroenterol Res Pract 2016:1895694. doi:10.1155/2016/1895694

20. Tibble J, Sigthorsson G, Foster R, Scott D, Fagerhol M, Roseth A, Bjarnason I (1999) High prevalence of NSAID enteropathy as shown by a simple faecal test. Gut 45:362-366 21. Tibble J, Sigthorsson G, Foster R, Sherwood R, Fagerhol M, Bjarnason I (2001) Faecal calprotectin and faecal occult blood tests in the diagnosis of colorectal carcinoma and adenoma. Gut 49 (402-408)

22. Present D, Rutgeerts $P$, Targan S, Hanauer S, Mayer L, van Hogezand R, Podolsky D, Sands BE, Braakman T, DeWoody K, Schaible T, Van Deventer SJ (1999) Infliximab for the

This article is protected by copyright. All rights reserved. 
treatment of fistulas in patients with Crohn's disease. New England Journal of Medicine 340 (6):1398-1405

23. Pittet V, Juillerat $P$, Michetti $P$, Vader JP, Burnand B, Rogler $G$, Beglinger $C$, Seibold F, Mottet C, Felley C, Gonvers JJ, Froehlich F, Swiss IBDCSG (2010) Appropriateness of therapy for fistulizing Crohn's disease: findings from a national inflammatory bowel disease cohort. Aliment Pharmacol Ther 32 (8):1007-1016. doi:10.1111/j.1365-2036.2010.04434.x

24. Lee JB, Yoon SG, Park KJ, Lee KY, Kim DD, Yoon SN, Yu CS, Korean IBDSG (2015) The Clinical Features and Predictive Risk Factors for Reoperation in Patients With Perianal Crohn Diseases; A Multi-Center Study of a Korean Inflammatory Bowel Disease Study Group. Ann Coloproctol 31 (5):176-181. doi:10.3393/ac.2015.31.5.176

25. Duff S, Sagar PM, Rao M, Dolling S, Sprakes M, Hamlin PJ (2012) Infliximab and surgical treatment of complex anal Crohn's disease. Colorectal Dis 14 (8):972-976.

doi:10.1111/j.1463-1318.2011.02811.x

26. O'Riordan JM, Datta I, Johnston C, Baxter NN (2012) A systematic review of the anal fistula plug for patients with Crohn's and non-Crohn's related fistula-in-ano. Dis Colon Rectum 55 (3):351-358. doi:10.1097/DCR.0b013e318239d1e4

27. Gingold DS, Murrell ZA, Fleshner PR (2014) A prospective evaluation of the ligation of the intersphincteric tract procedure for complex anal fistula in patients with Crohn's disease. Ann Surg 260 (6):1057-1061. doi:10.1097/SLA.0000000000000479

28. Yassin NA, Askari A, Warusavitarne J, Faiz OD, Athanasiou T, Phillips RK, Hart AL (2014) Systematic review: the combined surgical and medical treatment of fistulising perianal Crohn's disease. Aliment Pharmacol Ther 40 (7):741-749. doi:10.1111/apt.12906 29. de Groof EJ, Sahami S, Lucas C, Ponsioen CY, Bemelman WA, Buskens CJ (2016) Treatment of perianal fistulas in Crohn's disease: a systematic review and meta-analysis comparing seton drainage and anti-TNF treatment. Colorectal Dis. doi:10.1111/codi.13311 30. de Groof EJ, Buskens CJ, Ponsioen CY, Dijkgraaf MG, D'Haens GR, Srivastava N, van Acker GJ, Jansen JM, Gerhards MF, Dijkstra G, Lange JF, Witteman BJ, Kruyt PM, Pronk A, van Tuyl SA, Bodelier A, Crolla RM, West RL, Vrijland WW, Consten EC, Brink MA, Tuynman JB, de Boer NK, Breukink SO, Pierik MJ, Oldenburg B, van der Meulen AE, Bonsing BA, Spinelli A, Danese S, Sacchi M, Warusavitarne J, Hart A, Yassin NA, Kennelly RP, Cullen GJ, Winter DC, Hawthorne AB, Torkington J, Bemelman WA (2015) Multimodal treatment of perianal fistulas in Crohn's disease: seton versus anti-TNF versus advancement plasty (PISA): study protocol for a randomized controlled trial. Trials 16:366. doi:10.1186/s13063-015-0831-x 31. Corte H, Maggiori L, Treton X, Lefevre JH, Ferron M, Panis Y (2015) Rectovaginal Fistula: What Is the Optimal Strategy?: An Analysis of 79 Patients Undergoing 286 Procedures. Ann Surg 262 (5):855-860; discussion 860-851. doi:10.1097/SLA.0000000000001461 32. Tozer PJ, Balmforth D, Kayani B, Rahbour G, Hart AL, Phillips RK (2013) Surgical management of rectovaginal fistula in a tertiary referral centre: many techniques are needed. Colorectal Dis 15 (7):871-877. doi:10.1111/codi.12114

33. Archampong D, Borowski D, Wille-Jorgensen P, Iversen LH (2012) Workload and surgeon's specialty for outcome after colorectal cancer surgery. Cochrane Database Syst Rev 3:CD005391. doi:10.1002/14651858.CD005391.pub3

34. Faiz O (2014) The volume-outcome relationship in colorectal surgery. Tech Coloproctol 18 (10):961-962. doi:10.1007/s10151-014-1191-3

35. Kasparek MS, Glatzle J, Temeltcheva T, Mueller MH, Koenigsrainer A, Kreis ME (2007) Long-term quality of life in patients with Crohn's disease and perianal fistulas: influence of fecal diversion. Dis Colon Rectum 50 (12):2067-2074. doi:10.1007/s10350-007-9006-5

This article is protected by copyright. All rights reserved. 


\section{Appendix: pCD Collaborative authors (to be PubMed citable)}

A Abbas, S Adegbola, M Alfa-Wali, L Ashken, P Barrow, RR Brady, D Couch, A Engledow, E Gammeri, M Gill, M Kadhum, H Kankam, S Kaptanis, P Labib, J Luck , K Majid, J Martin, A Moss, J Nicholson, MR Iqbal, B Singh, N Sengupta, C Sproson, B Stubbs, F Suker, P Tozer, G van Boxel, $\mathrm{N}$ Ventham.

\section{Acknowledgements}

This work was funded by the Bowel Disease Research Foundation.

\begin{tabular}{|c|c|c|c|c|c|}
\hline 1 & \multicolumn{4}{|c|}{ Response (\%) } & \multirow[b]{2}{*}{ Missing } \\
\hline In the acute setting: & Always & Frequently & Occasionally & Never & \\
\hline \multirow{2}{*}{$\begin{array}{l}\text { Would you use } \\
\text { antibiotics? }\end{array}$} & 61 (39.6\%) & 45 (29.2\%) & 43 (27.9\%) & $2(1.3 \%)$ & 3 (1.9\%) \\
\hline & $\begin{array}{c}\text { Pre- } \\
\text { operatively }\end{array}$ & $\begin{array}{l}\text { Anaesthetic } \\
\text { induction }\end{array}$ & Post-operatively & Other & Missing \\
\hline $\begin{array}{c}\text { When would you start } \\
\text { them? }\end{array}$ & 65 (42.2\%) & 63 (40.9\%) & $10(6.5 \%)$ & $7(4.5 \%)$ & $9(5.8 \%)$ \\
\hline List & Ciprofloxacin & Metronidazole & Co-amoxiclav & Gentamicin & \\
\hline \multirow{2}{*}{$\begin{array}{c}\text { What antibiotics would } \\
\text { you use? }\end{array}$} & $31(20.1 \%)$ & $121(78.5 \%)$ & $54(35.1 \%)$ & $22(14.2 \%)$ & - \\
\hline & Always & Frequently & Occasionally & Never & Missing \\
\hline $\begin{array}{l}\text { Would you obtain pre- } \\
\text { operative imaging? }\end{array}$ & $11(7.1 \%)$ & 57 (37.0\%) & 80 (51.9\%) & $5(3.2 \%)$ & $1(0.6 \%)$ \\
\hline $\begin{array}{c}\text { If the diagnosis of } \\
\text { Crohn's disease was not } \\
\text { established, would you } \\
\text { use: }\end{array}$ & Always & Frequently & Occasionally & Never & Missing \\
\hline Faecal Calprotectin & $33(21.4 \%)$ & $36(23.3 \%)$ & 39 (25.3\%) & $36(23.3 \%)$ & $10(6.5 \%)$ \\
\hline Colonoscopy & $88(57.1 \%)$ & 45 (29.2\%) & $16(10.3 \%)$ & $5(3.2 \%)$ & 0 \\
\hline Flexible sigmoidoscopy & $26(16.8 \%)$ & $37(24.0 \%)$ & 60 (38.9\%) & $28(18.2 \%)$ & $3(1.9 \%)$ \\
\hline $\begin{array}{l}\text { Video Capsule } \\
\text { Endoscopy }\end{array}$ & 0 & $4(2.6 \%)$ & $83(53.8 \%)$ & $61(38.6 \%)$ & $6(3.8 \%)$ \\
\hline MR Small Bowel & 0 & 0 & $23(14.9 \%)$ & $\begin{array}{c}125 \\
(81.1 \%) \\
\end{array}$ & $6(3.8 \%)$ \\
\hline
\end{tabular}

Table 1: Summary of initial assessment and pre-operative management of perianal 


\section{Response (\%)}

\begin{tabular}{cccccc}
\hline $\begin{array}{c}\text { If you were doing the case, } \\
\text { would you consider: }\end{array}$ & Always & Frequently & Occasionally & Never & Missing \\
\hline $\begin{array}{c}\text { Incision and drainage of } \\
\text { abscess }\end{array}$ & $50(32.4 \%)$ & $48(31.1 \%)$ & $44(28.6 \%)$ & $8(5.1 \%)$ & $4(2.5 \%)$ \\
$\begin{array}{c}\text { Insertion of draining seton } \\
\text { Insertion of cutting seton }\end{array}$ & $48(31.1 \%)$ & $61(43.5 \%)$ & $35(22.7 \%)$ & $1(0.6 \%)$ & $10(6.4 \%)$ \\
$\begin{array}{c}\text { Excision of track } \\
\text { If you were advising a }\end{array}$ & $1(0.6 \%)$ & 0 & $13(8.4 \%)$ & $138(89.6 \%)$ & $4(2.5 \%)$ \\
$\begin{array}{c}\text { colleague or registrar, } \\
\text { would you advise: }\end{array}$ & Always & Frequently & Occasionally & Never & Missing \\
$\begin{array}{c}\text { Incision and drainage of } \\
\text { abscess }\end{array}$ & $67(43.5 \%)$ & $46(29.8 \%)$ & $31(20.1 \%)$ & $7(4.5 \%)$ & $3(1.9 \%)$ \\
$\begin{array}{c}\text { Insertion of draining seton } \\
\text { Insertion of cutting seton }\end{array}$ & $30(19.4 \%)$ & $50(32.4 \%)$ & $60(38.9 \%)$ & $11(7.1 \%)$ & $3(1.9 \%)$ \\
Excision of track & 0 & 0 & $4(2.5 \%)$ & $146(94.8 \%)$ & $4(2.5 \%)$ \\
\hline
\end{tabular}

Table 2: Practice around surgery in the acute/urgent setting.

\section{Response (\%)}

\begin{tabular}{cccccc}
\hline $\begin{array}{c}\text { At first planned EUA, } \\
\text { would you consider }\end{array}$ & Always & Frequently & Occasionally & Never & Missing \\
\hline $\begin{array}{c}\text { Insertion of draining seton } \\
\text { Insertion of cutting seton }\end{array}$ & $48(31.1 \%)$ & $61(43.5 \%)$ & $35(22.7 \%)$ & $1(0.6 \%)$ & $10(6.4 \%)$ \\
\hline $\begin{array}{c}\text { Excision of track } \\
\text { Fistulotomy }\end{array}$ & $1(0.6 \%)$ & 0 & $45(29.2 \%)$ & $104(67.5 \%)$ & $4(2.5 \%)$ \\
\hline $\begin{array}{c}\text { Faecal diversion } \\
\text { After first elective }\end{array}$ & 0 & $5(3.2 \%)$ & $88(57.1 \%)$ & $55(35.7 \%)$ & $6(3.8 \%)$ \\
$\begin{array}{c}\text { procedure, would you } \\
\text { routinely plan for: }\end{array}$ & Always & Frequently & Occasionally & Never & Missing \\
$\begin{array}{c}\text { Post-operative antibiotics } \boldsymbol{t} \\
\text { Post-operative imaging if } \\
\text { fistula found } \boldsymbol{t}\end{array}$ & $15(11.2 \%)$ & $21(15.7 \%)$ & $79(59.0 \%)$ & $53(34.4 \%)$ & $47(30.5 \%)$ \\
\hline $\begin{array}{c}\text { Post-operative imaging if } \\
\text { no-fistula found } \boldsymbol{t}\end{array}$ & $85(36.0 \%)$ & $48(36.0 \%)$ & $32(24.0 \%)$ & $13(9.7 \%)$ & $5(3.7 \%)$ \\
\hline Repeat EUA $\boldsymbol{t}$ & $22(16.5 \%)$ & $47(35.3 \%)$ & $54(40.6 \%)$ & $6(4.5 \%)$ & $4(3.0 \%)$ \\
\hline
\end{tabular}

Table 3: Summary of management around first planned examination under anaesthetic.

tPercentage based on 133 respondents from full survey as no equivalent response options used in pilot.

This article is protected by copyright. All rights reserved. 


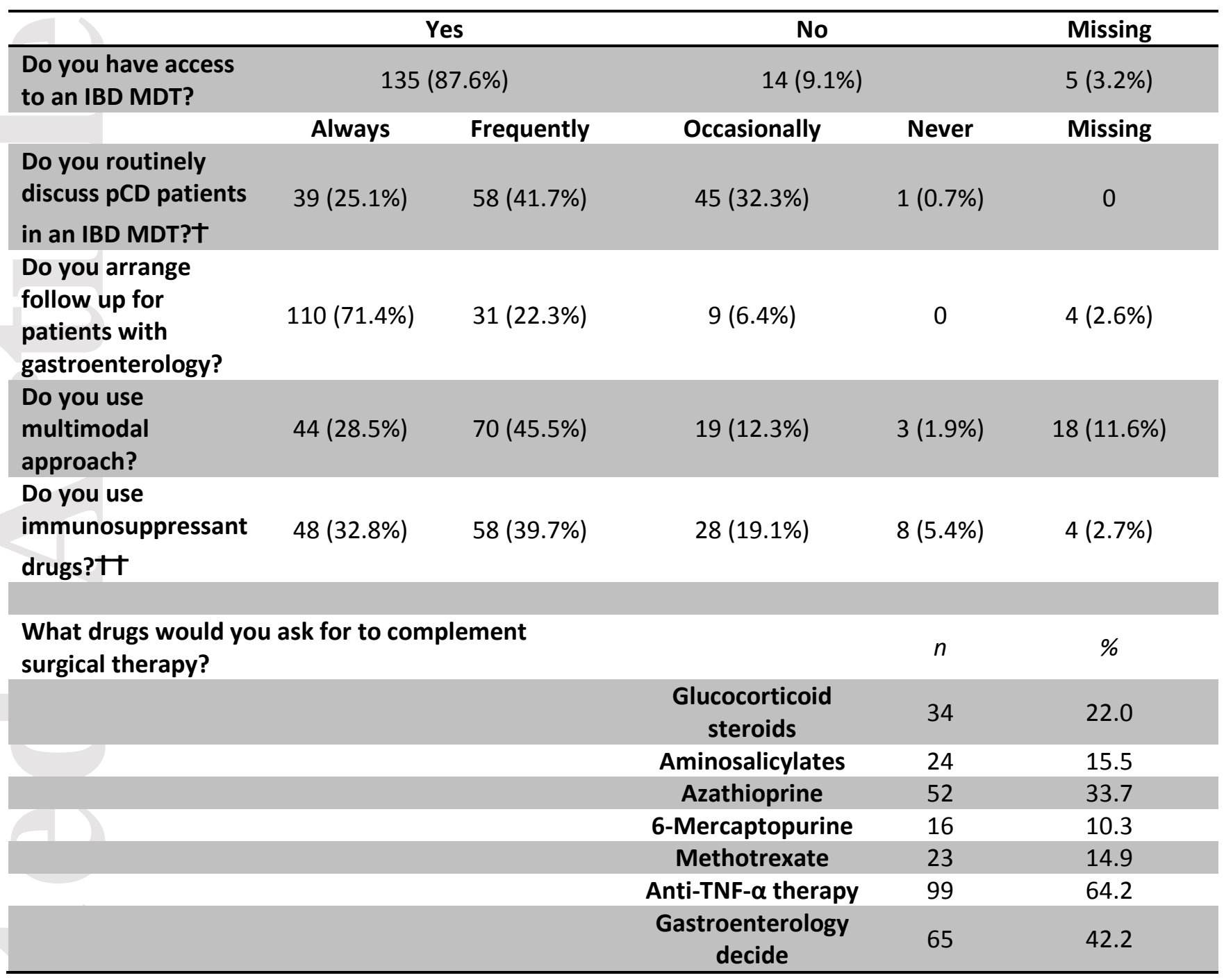

Table 4: Summary responses and multimodal management approaches used.

*Selected cases group was split into Frequently and Occasionally after pilot. TPercentage based on 143 respondents who replied 'Yes' to IBD MDT or missing responses (i.e. excludes those with no MDT). T+8 patients excluded as option 'selected cases' removed in full version.

This article is protected by copyright. All rights reserved. 


\begin{tabular}{ccc}
\hline Procedure & Perianal Fistula $(\mathbf{n = 1 5 4 )}$ & $\begin{array}{c}\text { Rectovaginal fistula } \\
(\mathbf{n}=64)\end{array}$ \\
\hline Removal of Seton only & $109(70.7 \%)$ & - \\
\hline Fistulotomy & $88(57.1 \%)$ & - \\
\hline Fistulectomy & $43(27.9 \%)$ & - \\
Fistula Plug & $56(36.4 \%)$ & $14(21.5 \%)$ \\
Advancement flap & $60(38.9 \%)$ & - \\
Fibrin Glue & $20(12.9 \%)$ & $3(4.6 \%)$ \\
LIFT & $46(29.8 \%)$ & - \\
OTSC & $2(1.2 \%)$ & - \\
VAAFT & $3(1.9 \%)$ & - \\
FiLaC & $1(0.6 \%)$ & $6(9.3 \%)$ \\
Local (Perineal) Flap & $12(7.8 \%)$ & $4(6.2 \%)$ \\
Martius Flap & - & $4(6.2 \%)$ \\
\hline Omental interposition & - & - \\
Diverting stoma & - & - \\
\hline Table 5: Definitive surgical procedures and their use in perianal and rectovaginal fistula
\end{tabular}

This article is protected by copyright. All rights reserved. 